\title{
IMPLEMENTASI KEBIJAKAN PENGADAAN RUMAH SINGGAH OLEH DINAS SOSIAL DI KOTA SUKABUMI
}

\author{
Faizal Nursamyono \\ Universitas Muhammadiyah Sukabumi \\ Email: fnursamyono@gmail.com
}

\begin{abstract}
Abstrak
Upaya pengadaan rumah singgah ini berlandaskan pada Peraturan Daerah Kota Sukabumi Nomor 6 Tahun 2016 tentang Penyelenggaraan Kesejahteraan Sosial. Tujuan penelitian ini adalah untuk mengetahui implementasi kebijakan penyelenggaraan kesejahteraan sosial oleh Dinas Sosial di Kota Sukabumi. Penelitian ini menggunakan metode kualitatif deskriptif dan menggunakan teori implementasi kebijakan publik menurut Edward III. Data diperoleh melalui observasi, wawancara, dan studi dokumentasi. Hasil penelitian mengungkapkan bahwa implementasi kebijakan penyelenggaraan kesejahteraan sosial oleh Dinas Sosial di Kota Sukabumi belum terlaksana secara maksimal, dikarenakan kurangnya sumber daya manusia dan tidak adanya fasilitas untuk pembinaan dan pelatihan/rehabilitasi seperti rumah singgah. Pemerintah Kota Sukabumi seharusnya memiliki rumah singgah untuk penanganan penyandang masalah kesejahteraan sosial agar dinas sosial dapat turut serta dalam pelaksanaan pembinaan dan pelatihan/rehabilitasi. Pemerintah Kota Sukabumi juga hendaknya membuat program pembinaan lanjutan, pembinaan lanjutan ini bertujuan untuk memelihara dan meningkatkan kemampuan sosial ekonomi dan mengembangkan rasa tanggung jawab serta kesadaran hidup bermasyarakat.
\end{abstract}

Kata Kunci: implementasi kebijakan, kesejahteraan sosial, rumah singgah, PMKS.

\begin{abstract}
The effort on providing shelter is based on Regional Regulation of Sukabumi city number 6 Yeat 2016 about the Implementation of Social Walfare. In the provision of shelter, several problems were found such as the lack of manpower and the absence of facilities for training/rehabilitation. The research was aimed at finding out the implementation of sicial walfare policy at Department of Social of Sukabumi city, having informants amounted to 4 persons. The research applied qualitative descriptive method with public policy implementation theory from Edward III. The data were acquired from observation, interview and documentation. The procedures of data validation were conducted by triangulation sources. The result of the research convey that the implementation of social walfare by Department of Social in Sukabumi city has not been implemented maximally, due to the lack of manpower and the absence of facilities for training/rehabilitation in term of shelter. The government of Sukabumi city are supposed to own shelter in order to handle PMKS so that the department of social can participate in the implementation of the training/rehabilitation. The government of Sukabumi city shall also create further training program which is aimed for maintaining and improving social economic ability and developing the responsibility as well as social living awareness.
\end{abstract}

Keywords: policy implementation, social welfare, shelter, PMKS. 


\section{A. PENDAHULUAN}

Penyandang masalah kesejahteraan sosial atau disingkat menjadi PMKS, sesungguhnya mereka adalah masyarakat yang tersisihkan dan termarginalkan dari perlakuan kasih sayang, karena kebanyakan dari mereka harus berhadapan dengan lingkungan kota yang keras dan sangat tidak bersahabat untuk mereka. Mereka harus bertahan hidup dengan cara-cara yang kurang atau bahkan tidak dapat diterima oleh masyarakat umum, sekedar untuk menghilangkan rasa lapar dan keterpaksaan untuk membantu keluarganya. Merekapun sering dicap sebagai pengganggu ketertiban dan membuat kota menjadi kotor, sehingga yang namanya razia atau disebut dengan penjangkauan bukan lagi hal yang mengagetkan mereka. PMKS merupakan komunitas yang paling beresiko mengalami kegagalan dalam hidup mereka, dikarenakan permasalahan ekonomi, ditelantarkan keluarga, dll. Peran serta pemerintah dalam menuntaskan permasalahan tersebut yaitu dengan memberikan perlindungan dan pembinaan/rehabilitasi terhadap PMKS melalui dinas. Dinas yang bersangkutan disini yaitu Dinas Sosial Kota Sukabumi.

Penjangkauan adalah salah satu solusi dalam pengentasan masalah PMKS dijalanan. Namun realitanya penjangkauan mengalami kebuntuan, dikarenakan tidak adanya tindak lanjut setelah penjangkauan dilaksanakan. Seharusnya tahap selanjutnya setelah penjangkauan dilaksanakan yaitu tahap rehabilitasi, dimana para PMKS diberikan pembinaan dan keterampilan. Tujuan rehabilitasi sosial sebagaimana dimaksudkan dalam Pasal 16 Peraturan Daerah Kota Sukabumi No. 6 Tahun 2016, rehabilitasi sosial bertujuan untuk memulihkan dan mengembangkan kemampuan PMKS (Penyandang Masalah Kesejahteraan Sosial) yang mengalami disfungsi sosial agar dapat melaksanakan fungsi sosial secara wajar, pemulihan dan pengembangan ditujukan untuk mengembalikan keberfungsian secara fisik, mental, dan sosial, serta memberikan dan meningkatkan keterampilan.

Berikut disajikan data jumlah PMKS pada tahun 2018 dalam table 1 sebagai berikut:

Tabel 1 Data PMKS 2018

\begin{tabular}{clc}
\hline No. & \multicolumn{1}{c}{ Jenis PMKS } & Jumlah \\
\hline 1 & Anak Balita Terlantar & 84 \\
2 & Anak Terlantar & 345 \\
3 & Anak Berhadapan Dengan Hukum & 49 \\
4 & Anak Jalanan & 49 \\
5 & Anak Dengan Kedisabilitasan (ADK) & 189 \\
6 & Anak yang menjadi korban tindakan kekerasan & 84 \\
7 & Anak yang memerlukan perlindungan khusus & 78 \\
8 & Lanjut Usia Terlantar & 1.164 \\
9 & Penyandang Disabilitas & 707 \\
10 & Tuna Susila & 9
\end{tabular}


ARTIKEL

\begin{tabular}{llc}
\hline 11 & Gelandangan & 13 \\
12 & Pengemis & 48 \\
13 & Pemulung & 258 \\
14 & Kelompok Minoritas & 79 \\
15 & Bekas warga binaan lembaga pemasyarakatan & 70 \\
16 & Orang dengan HIV / AIDS (ODHA) & 1 \\
17 & Korban penyalahgunaan NAFZA & 35 \\
18 & Korban Trafficking & 46 \\
19 & Korban tindak kekerasan & 13 \\
20 & Pekerja Migran Bermasalah & 23 \\
21 & Korban Bencana Alam & 19 \\
22 & Korban Bencana Sosial & 55 \\
23 & Perempuan Rawan Sosial Ekonomi & 2.161 \\
24 & Fakir Miskin & 15.670 \\
25 & Keluarga Bermasalah Sosial Psikologis & 67 \\
26 & Komunitas Adat Terpencil & - \\
\hline
\end{tabular}

Sumber: Dinas Sosial Kota Sukabumi Tahun (2018)

Pemerintah dalam memberikan pelayanan terhadap PMKS tentunya memerlukan sarana dan prasarana. Dalam pasal 11 ayat 1 Peraturan Daerah Kota Sukabumi No 06 Tahun 2016 tentang Penyelenggaraan Kesejahteraan Sosial. Sarana dan Prasarana Penyelenggaraan Kesejahteraan Sosial di Daerah meliputi: pusat kesejahteraan sosial, rumah singgah, dan rumah perlindungan sosial. Namun nyatanya pasal tersebut belum rampung sepenuhnya, salah satu penyebabnya yaitu belum adanya rumah singgah. Keberadaan rumah singgah tentunya sangat diharapkan juga oleh pihak Dinas Sosial sendiri, agar dapat melaksanakan tugas pelayanan secara maksimal.

Pelayanan secara maksimal juga tidak hanya bergantung kepada sarana dan prasarana saja, namun faktor sumber daya manusianya pun harus mencukupi. Kondisi sumber daya manusia di Dinas Sosial sendiri mengalami kekurangan, sumber daya manusia yang dibutuhkan setiap bidang adalah 16 orang, namun nyatanya hanya ada 6 orang di setiap bidang nya. Hal tersebut menjadi penyebab dimana adanya keterlambatan pelayanan yang diberikan oleh pihan Dinas Sosial dalam pengentasan permasalah PMKS.

Berikut adalah fenomena masalah yang terjadi tentang penyelenggaraan kesejahteraan sosial di kota Sukabumi yang diantaranya yaitu sebagai berikut:

1. Tidak adanya tindak lanjut setelah dilakukannya razia atau disebut dengan penjangkauan. Seharusnya setelah penjangkauan para PMKS diberikan pembinaan dan perlindungan.

2. Belum adanya sarana dan prasarana untuk memberikan pembinaan dan pelatihan/rehabilitasi, yaitu Rumah Singgah. 
3. Dinas Sosial Kota Sukabumi ternyata masih kekurangan SDM dalam pengentasan permasalahan PMKS.

Dengan adanya Peraturan Daerah Kota Sukabumi Nomor 6 Tahun 2016 tentang Penyelenggaraan Kesejahteraan Sosial, artinya adanya upaya yang terarah, terpadu, dan berkelanjutan yang dilakukan Pemerintah, Pemerintah Daerah, dan masyarakat dalam bentuk pelayanan sosial guna memenuhi kebutuhan dasar setiap warga negara, yang meliputi rehabilitasi sosial, jaminan sosial, pemberdayaan sosial, dan perlindungan sosial.

Keberadaan rumah singgah sangat penting, berbagai perubahan terjadi pada anak jalanan di rumah singgah, baik perubahan yang berhubungan dengan kondisi fisik maupun berhubungan dengan kondisi lingkungan. Perubahan-perubahan yang terjadi pada anak jalanan dipengaruhi oleh apa yang mereka terima di rumah singgah. Begitupun apabila Kota Sukabumi mempunyai rumah singgah tentunya dapat berpengaruh baik terhadap PMKS yang nantinya mengalami banyak perubahan baik. Maka dari itu peran penting dari rumah singgah sangatlah dibutuhkan untuk PMKS agar dapat mengembalikan fungsi sosial PMKS (Anandar, Wibhawa \& Wiboro, 2015).

Tidak adanya rumah singgah menjadi kendala yang sangat menyulitkan. Pelaksanaan kebijakan pembinaan anak jalanan yang dilakukan pemerintah Kota Bandar Lampung melalui Dinas Sosial dan masyarakat masih menuai berbagai permasalahan seperti keterbatasan SDM, dana, sarana dan prasarana. Hal ini mengakibatkan usaha yang dilakukan oleh Dinas Sosial belum menunjukan hasil yang diharapkan oleh pemerintah Kota Bandar Lampung. Pemerintah Bandar Lampung seharusnya memiliki panti rehabilitasi sendiri agar Dinas Sosial dapat turut serta dalam pelksanaan pembinaan. Pemerintah juga hendaknya membuat program pembinaan lanjutan ini bertujuan untuk memelihara dan meningkatkan kemampuan sosial ekonomi dan mengembangkan rasa tanggungjawab serta kesadaran hidup bermasyarakat (Arifin, 2017).

Dengan adanya rumah singgah pun, pemerintah harus memperhatikan persolaan lanjutannya, yaitu dengan membuat program-program yang dapat diterima dengan baik oleh PMKS. Pembinaan akhlak yang diberikan kepada anak-anak jalanan di Cahaya Anak Negeri diantaranya akhlak terhadap Allah, akhlak terhadap diri sendiri, dan akhlak terhadap sesama. Adapun metode yang digunakan dalam pembinaan akhlak tersebut adalah metode nasihat, metode teladan, metode pembiasaan dan metode imbalan dan ancaman. Kendala utama yang dihadapi dalam pembinaan akhlak bagi anak jalanan ini adalah sulitnya mengatur anak jalanan yang cenderung berwatak keras. Upaya yang dilakukan untuk mengatasi kendala 
tersebut adalah dengan memasuki dunia mereka, agar mereka merasa nyaman dengan pembina. Hasil pembinaan akhlak tersebut dapat dilihat dari perubahan yang signifikan dari pengetahuan dan perilaku mereka yang lebih baik. Dalam skripsi tersebut bisa dilihat bahwa pentingnya komunikasi dan pengetahuan dalam pemberian pembinaan terhadap anak jalanan agar diterima dengan baik oleh anak jalanan sehingga membuahkan hasil yang baik (Sirojudin, 2015).

Penelitian ini bertujuan untuk mengetahui implementasi kebijakan penyelenggaraan kesejahteraan sosial oleh Dinas Sosial di Kota Sukabumi (upaya pengadaan rumah singgah) dan mengetahui faktor-faktor yang menghambatan dalam implementasi kebijakan tersebut.

\section{B. KAJIAN PUSTAKA}

Istilah kebijakan (policy) seringkali penggunaannya dipertukarkan dengan istilahistilah lain seperti tujuan (goals), program, keputusan, undang-undang, ketentuan-ketentuan, usulan-usulan dan rancangan besar. Menurut Anderson, "kebijakan adalah suatu tindakan yang mempunyai tujuan yang dilakukan seseorang pelaku atau sejumlah pelaku untuk memecahkan suatu masalah". Selanjutnya Anderson mengklasifikasi kebijakan menjadi dua: substantif dan prosedural. Kebijakan substantif yaitu apa yang harus dikerjakan oleh pemerintah, sedangkan kebijakan prosedural yaitu siapa dan bagaimana kebijakan tersebut diselenggarakan (Tahir, 2015).

Implementasi intinya adalah kegiatan untuk mendistribusikan keluaran kebijakan (to deliver policy output) yang dilakukan oleh para implementer kepada kelompok sasaran (target group) sebagai upaya untuk mewujudkan tujuan kebijakan (Purwanto \& Sulistyastuti, 2015). Tujuan kebijakan diharapkan akan muncul manakala policy output dapat diterima dan dimanfaatkan dengan baik oleh kelompok sasaran sehingga dalam jangka panjang hasil kebijakan akan mampu diwujudkan. Model implementasi kebijakan dalam penelitian ini menggunakan model implementasi kebijakan menurut Edward III, mengemukakan ada 4 variabel yang mempengaruhi implementasi kebijakan yaitu komunikasi, sumberdaya, disposisi dan struktur birokrasi (Agustino, 2016).

Kesejahteraan sosial adalah kondisi terpenuhinya kebutuhan material, spiritual, dan sosial warga negara agar dapat hidup layak dan mampu mengembangkan diri, sehingga dapat melaksanakan fungsi sosialnya (Peraturan Pemerintah Republik Indonesia No. 39 Tahun 2012). Dalam peraturan tersebut yang menjadi sasaran kebijakannya yaitu PMKS. Dalam Pasal 1 ayat 14 Peraturan Daerah Kota Sukabumi No. 6 Tahun 2016, disebutkan bahwa 
Penyandang Masalah Kesejahteraan Sosial yang selanjutnya disingkat PMKS adalah perorangan, kelompok, atau kelompok masyarakat yang sedang mengalami hambatan sosial, moral, dan material baik yang berasal dari dalam maupun dari luar dirinya sehingga tidak dapat melaksanakan fungsinya untuk memenuhi kebutuhan minimum baik jasmani, rohani, maupun sosial.

Dalam pengertian Rumah Singgah secara terminologi rumah berarti bangunan untuk tempat tinggal, sedangkan singgah adalah mampir atau berhenti sebentar di suatu tempat ketika dalam perjalanan. Dari pengertian diatas rumah singgah bisa diartikan sebagai bangunan atau tempat tinggal yang di tempati dalam waktu yang tidak lama. Sedangkan secara etimologi, Rumah Singgah adalah suatu wahana yang di persiapkan sebagai perantara antara anak jalanan dengan pihak-pihak yang membantu mereka. Rumah Singgah merupakan suatu shelter yang berfungsi sebagai tempat tinggal, pusat kegiatan dan pusat informasi bagi anak jalanan. Dari pengertian diatas Rumah Singgah merupakan proses informal yang memberikan suasana resosialisasi kepada anak jalanan terhadap sistem nilai dan norma yang berlaku di masyarakat setempat. Rumah Singgah merupakan tahap awal bagi seorang anak untuk memperoleh pelayanan selanjutnya, oleh karenanya penting menciptakan Rumah Singgah sebagai tempat yang aman, nyaman, menarik, dan menyenangkan bagi anak jalanan sehingga anak akan selalu di Rumah Singgah.

Dalam penelitian ini, peneliti menggunakan 2 penelitian terdahulu sebagai bahan rujukan dalam penelitian agar penelitian dapat mendapatkan informasi lebih yang dapat membantu peneliti dan juga merupakan perbandingan antara peneletian ini dengan penelitian terdahulu lainnya : Penelitian pertama yang menjadi pedoman awal adalah penelitian dengan judul "Peran Rumah Singgah Cahaya Anak Negeri Dalam Meningkatkan Akhlak Anak Jalanan" yang ditulis oleh Muhamad Sirojudin Universitas Islam Negeri Syarif Hidayatullah jurusan manajemen dakwah tahun 2015. Metode dalam penelitian dari penelitian ini adalah dengan metode kualitatif yang bersifat deskriptif, dengan teknik mengumpulkan data menggunakan observasi, wawancara, dan dokumen. Latar belakang yang melatarbelakangi peneliti ini adalah Kurangnya penanganan terhadap permasalahan anak jalanan terutama kurangnya pembinaan akhlak bagi anak jalanan. Penelitian selanjutnya yang dijadikan rujukan dalam penelitian adalah penelitian dengan judul "Pembinaan Anak Jalanan Oleh Dinas Sosial Kota Bandar Lampung” yang ditulis oleh Syamsul Arifin Universitas Islam Negeri Raden Intan Lampung jurusan pemikiran politik islam tahun 2017. Metode dalam penelitian dari penelitian ini adalah dengan metode kualitatif, dengan teknik mengumpulkan 
data menggunakan observasi, wawancara, dan dokumentasi. Latar belakang yang melatarbelakangi peneliti ini adalah karena terbatasnya SDM, dana, sarana dan prasarana dalam pelaksanaan program pembinaan. Yang membedakan peneliti terdahulu dengan peneliti yang lakukan sekarang adalah dalam hal penelitian ini peneliti ingin mengetahui lebih dalam mengenai bagaimana implementasi kebijakan penyelenggaraan kesejahteraan sosial oleh Dinas Sosial di Kota Sukabumi (upaya pengadaan rumah singgah) dan apa hambatan dalam implementasi kebijakan tersebut.

Konsep penelitan ini adalah dengan adanya Peratuan Daerah Kota Sukabumi No. 06 Tahun 2016, tentang Penyelenggaraan Kesejahteraan Sosial. Dalam penelitian ini, peneliti ingin menganalisis implementasi kebijakan tersebut dengan teori George C. Edward III yang mengemukakan bahwa implementasi kebijakan dapat dipengaruhi oleh komunikasi, sumber daya, disposisi dan struktur birokrasi. Alasan peneliti menggunakan teori tersebut adalah karena teori tersebut cocok dan sesuai untuk digunakan dalam menelaah tentang implementasi kebijakan penyelenggaraan kesejahteraan sosisal (studi kasus rumah singgah).

\section{METODE PENELITIAN}

Penelitian ini merupakan penelitian deskriptif dengan pendekatan kualitatif. Dengan menggunakan desain penelitian deskriptif dengan pendekatan kualitatif bertujuan untuk menggali mengenai fakta mengenai implementasi kebijakan penyelenggaraan kesejahteraan sosial (upaya pengadaan rumah singgah). Dalam penelitian ini, pengumpulan data dilakukan pada natural setting (kondisi yang alamiah), sumber data primer, dan teknik pengumpulan data lebih banyak pada observasi berperan serta, wawancara mendalam, dan dokumentasi.

Observasi, menurut Nasution, observasi adalah dasar semua ilmu pengetahuan. Para ilmuwan hanya dapat bekerja berdasarkan data, yaitu fakta mengenai dunia kenyataan yang diperoleh melalui observasi (Sugiyono, 2016). Menurut Esterberg, wawancara merupakan pertemuan dua orang untuk bertukar informasi dan ide melalui tanya jawab, sehingga dapat dikonstruksikan makna dalam suatu topik tertentu (Sugiyono, 2016). Dan ketiga yaitu dokumentasi, Dokumen merupakan catatan peristiwa yang sudah berlalu. Dokumen bisa berbentuk tulisan, gambar, atau karya-karya monumental dari seseorang.

Validasi data dalam penelitian ini yaitu menggunakan teknik triangulasi sumber, untuk menguji kredibilitas data dilakukan dengan cara mengecek data yang telah diperoleh melalui beberapa sumber (Sugiyono, 2016). Teknik analisis data dalam penelitian ini dilakukan secara induktif berdasarkan fakta-fakta yang ditemukan. 


\section{HASIL DAN PEMBAHASAN}

Menurut Edward III ada empat variabel dalam kebijakan publik, yaitu komunikasi, sumberdaya, disposisi, struktur birokrasi. Keempat variabel tersebut hubungannya saling berkaitan, pertanyaan dalam wawancara yang peneliti gunakan mengacu kepada teori tersebut untuk mengetahui bagaimana keberhasilan dan kegagalan dari implementasi kebijakan penyelenggaraan kesejahteraan sosial.

\section{Komunikasi}

Berdasarkan hasil observasi dan wawancara tersebut dapat diinterpretasikan bahwa masyarakat maupun PMKS sendiri belum mengetahui tentang rumah singgah, hal ini dapat di lihat dari ungkapan yang di kemukakan oleh informan 1, bahwa terjadinya kendala mengenai ketidaktahuan masyarakat maupun PMKS mengenai rumah singgah dikarenakan Dinas Sosial Kota Sukabumi belum mempunyai rumah singgah sampai dengan tahun ini yaitu 2019, namun rumah singgah baru akan dibangun oleh pemerintah provinsi dan pemerintah Kota Sukabumi sebagai pelaksananya. Kemudian ungkapan yang dikemukakan oleh informan 3 dan informan 4, bahwa mereka mereka tidak mengetahui tentang adanya sosialisasi mengenai rumah singgah maupun tentang apa itu rumah singgah.

Komunikasi merupakan mekanisme sekaligus syarat utama dalam pembentukan keberhasilan pelaksanaan kebijakan. Apabila dilihat dari teori menurut Edward III, didalam komunikasi terdapat tiga indikator yang dapat dipakai (atau digunakan) dalam mengukur keberhasilan, yaitu: transmisi, kejelasan dan konsisten.

\section{a. Transmisi}

Sejauh ini komunikasi yang terjalin antara dinas terkait yaitu Dinas Sosial Kota Sukabumi dengan informan 3 dan informan 4 bisa dikategorikan belum baik, hal tersebut dikarenakan informan 3 dan informan 4 tidak mengetahui tentang adanya sosialisasi dan bahkan hanya menebak-nebak saja mengenai apa itu rumah singgah yang mereka ketahui. Kemudian peneliti menjelaskan tentang rumah singgah kepada informan3 dan informan 4. Setelah penjelasan tersebut, tanggapan dari informan 3 dan informan 4 adalah meharapkan agar segera terlaksananya rumah singgah tersebut. Hal tersebut diatas kemudian diluruskan dengan tanggapan dari informan 1 yang mengemukakan bahwa rumah singgah belum dikenal secara luas di masyarakat Kota Sukabumi, dikarenakan Dinas Sosial belum mempunyai rumah 
singgah sampai dengan tahun ini yaitu 2019. Rumah singgah baru akan dibangun oleh pemerintah provinsi dan pemerintah Kota Sukabumi sebagai pelaksananya.

b. Kejelasan

Sejauh ini kejelasan dalam komunikasi bisa disebut membingungkan, hal tersebut dikarenakan adanya ketidak terkaitannya antara Peraturan Daerah Kota Sukabumi No. 6 Tahun 2016 dengan realitanya di Kota Sukabumi, yaitu dalam PERDA tersebut dengan jelas menerangkan bahwa rumah singgah itu harus ada namun pada pengimplementasian nya ternyata mengalami hambatan yang disebabkan karena Dinas Sosial Kota Sukabumi belum mempunyai tempat untuk rumah singgah tersebut. Hal tersebut diatas kemudian menyebabkan informan 3 dan informan 4 tidak mengetahui tentang ada atau tidaknya sosialisasi dan bahkan hanya menebak-nebak saja mengenai apa itu rumah singgah yang mereka ketahui.

c. Konsisten

Perintah yang diberikan dalam peksanaan suatu komunikasi belum dapat bisa dikatakan konsisten, hal tersebut dikarenakan Dinas Sosial belum mempunyai rumah singgah sampai dengan tahun ini yaitu 2019. Rumah singgah baru akan dibangun oleh pemerintah provinsi dan pemerintah Kota Sukabumi sebagai pelaksananya. Hal tersebut diatas kemudian menyebabkan informan 3 dan informan 4 tidak mengetahui tentang ada atau tidaknya sosialisasi dan bahkan hanya menebak-nebak saja mengenai apa itu rumah singgah yang mereka ketahui.

Apabila Kota Sukabumi mempunyai rumah singgah tentunya dapat berpengaruh baik terhadap PMKS yang nantinya mengalami banyak perubahan baik. Maka dari itu peran penting dari rumah singgah sangatlah dibutuhkan untuk PMKS agar dapat mengembalikan fungsi sosial PMKS, namun peran komunikasi pun menjadi sangat penting dalam rumah singgah agar dalam pelaksanaan tidak ada nya miskomunikasi yang menyebabkan tidak efektifnya peran rumah singgah dalam mengurangi permasalahan PMKS di Kota Sukabumi.

Di Kota Sukabumi perlu adanya program-program yang efektif dalam mengurangi persoalan PMKS di Kota Sukabumi dan membangun komunikasi antara stakeholder dengan stakeholder ataupun stakeholder dengan masyarakat maupun PMKS. Komunikasi yang terjalin antar stakeholder harus baik dan jelas agar tidak terjadi permasalahan yang dapat menyebabkan tidak efektifnya penanganan permasalahan PMKS. Peran penting Dinas Sosial Kota Sukabumi dalam berkomunikasi haruslah diimbangi dengan pengetahuan yang luas agar 
PMKS dapat menerima dengan baik bentuk pembinaan yang diberikan oleh Dinas Sosial Kota Sukabumi meskipun belum ada rumah singgah.

2. Sumberdaya

Berdasarkan hasil observasi dan wawancara tersebut, dapat di interpretasikan bahwa sumber daya manusia sangat berpengaruh dalam pelaksanaan/pengimplementasian suatu kebijakan, serta keberadaan rumah singgah sangat dibutuhkan dalam pemberian pembinaan dan pelatihan/rehabilitasi. Namun pada realitanya sumber daya manusia yang ada di Dinas Sosial belum mencukupi, seharusnya di setiap bidang itu terdiri dari 16 orang, namun realitanya hanya ada 6 orang. Apabila dilihat dari teori menurut Edward III, keberhasilan proses implementasi kebijakan sangat tergantung dari kemampuan memanfaatkan sumber daya yang tersedia dan beberapa elemen, yaitu: staf, informasi, wewenang dan fasilitas.

a. Staf

Sampai dengan tahun 2019 sekarang Dinas Sosial Kota Sukabumi masih kekurangan sumber daya manusia, sehingga banyak sekali tumpang tindih jabatan. Dari yang diharapkan setiap seksi ada 16 orang staf, namun pada kenyataan nya hanya ada 6 orang staf, itupun sudah termasuk dengan kepala bidang dan kepala seksi. Hal tersebut juga lah yang menyebabkan kurangnya penanganan permasalahan PMKS hingga sekarang yang ditambah dengan belum adanya rumah singgah. Apabila permasalahan sumber daya manusia masih kurang dan tetap didiamkan tanpa ada penanganan atau penambahan sumber daya manusia, hal ini bisa menyebabkan gagalnya sebuah pelayanan dari Dinas Sosial dalam penanganan permasalah PMKS.

b. Informasi

Dalam implementasi kebijakan, informasi mempunyai dua bentuk yaitu:

1). Informasi yang berhubungan dengan cara melaksanakan kebijakan.

Dinas Sosial sangat mengetahui apa yang harus dilakukan dalam penanganan permasalahan PMKS, seperti program penjangkauan dan pelatihan. Namun hal tersebut tidak terlaksana secara keseluruhan dikarenakan kurang nya sumber daya manusia di Dinas Sosial Kota Sukabumi dan sasaran kebijakan pun yaitu informan 3 belum merasakan seluruhnya bentuk dari penjangkauan maupun pelatihan itu sendiri.

2). Informasi mengenai data kepatuhan dari para pelaksana terhadap peraturan dan regulasi pemerintah yang telah ditetapkan. 
Apabila dalam penelitian ini dinas terkait yaitu Dinas Sosial patuh terhadap hukum atau peraturan yang telah ada yaitu PERDA Kota Sukabumi No. 6 Tahun 2016 tentang penyelenggaraan kesejahteraan sosial, dan dilaksanakan atau diimplementasikan secara keseluruhan. Penanganan permasalahan PMKS akan dapat diatasi dengan efektif, namun pada realitanya PERDA tersebut belum sepenuhnya terlaksana secara optimal, hal tersebut disebabkan oleh kurangnya sumber daya manusia, dana, sara dan prasarana sehingga penanganan permasalahan PMKS belum dapat teratasi dengan efektif.

c. Wewenang

Kewenangan dalam penanganan permasalahan PMKS adalah Dinas Sosial Kota Sukabumi. meskipun pada dasarnya Dinas Sosial Kota Sukabumi mempunyai kewenangan tersebut, pada realitanya kewenangan tersebut terhambat dikarenakan kurangnya sumber daya manusia, dana, sarana dan prasarana sehingga kewenangan tersebut bisa dikatakan nihil.

d. Fasilitas

Fasilitas fisik juga merupakan faktor penting dalam implementasi kebijakan. Implementor mungkin memiliki staf yang mencukupi, mengerti apa yang harus dilakukannya, dan memiliki wewenang untuk melaksanakan tugasnya, tetapi tanpa adanya fasilitas pendukung (sarana dan prasarana) maka implementasi kebijakan tersebut tidak akan berhasil. Rumah singgah adalah sarana serta prasarana yang sangat dibutuhkan dalam penanganan permasalahan PMKS di Kota Sukabumi, namun hingga saat ini yaitu tahun 2019 rumah singgah belum ada. Rumah singgah baru akan ada di tahun 2020 dengan menggunakan bangunan BLK yang akan direlokasi menjadi rumah singgah.

Apabila Kota Sukabumi mempunyai rumah singgah tentunya dapat berpengaruh baik terhadap PMKS yang nantinya mengalami banyak perubahan baik. Maka dari itu peran penting dari rumah singgah sangatlah dibutuhkan untuk PMKS agar dapat mengembalikan fungsi sosial PMKS dan peran dari pemanfaatan sumber dayapun menjadi sangat penting dalam rumah singgah agar efektif dalam mengurangi permasalahan PMKS di Kota Sukabumi. Hal tersebutpun harus di imbangi dengan pemanfaatan sumber daya yang sesuai dan perlu ada nya program-program yang efektif dalam mengurangi permasalahan PMKS di Kota Sukabumi. 
Dalam pembinaan tentunya harus di imbangi dengan sumber daya yang mencukupi agar dalam pelaksanaan pembinaan bisa efektif. Terbatasnya SDM, dana, sarana dan prasarana dapat menunjukan bahwa sumber daya masih belum mencukupi dan dapat menimbulkan permasalahan, seperti kurang teratasinya penanganan permasalahan PMKS di Kota Sukabumi. Peran penting Dinas Sosial dalam pengoptimalan kualitas sumber daya agar PMKS dapat menerima dengan baik bentuk pembinaan yang diberikan oleh Dinas Sosial Kota Sukabumi meskipun belum ada rumah singgah.

\section{Disposisi}

Berdasarkan hasil observasi dan wawancara tersebut dapat diinterpretasikan bahwa disposisi atau sikap pelaksana kebijakan adalah faktor penting ketiga dalam pendekatan mengenai pelaksanaan suatu kebijakan publik. Jika pelaksanaan suatu kebijakan ingin efektif, maka para pelaksana kebijakan tidak hanya harus mengetahui apa yang akan dilakukan tetapi juga harus memiliki kemampuan untuk melaksanakannya, sehingga dalam praktiknya tidak terjadi bias. Namun pada realitanya disposisi atau sikap pelaksana kebijakan dalam menangani permasalahan PMKS dengan bentuk penjangkauan dan pelatihan belum terasakan oleh sasaran kebijakan yaitu informan 3 , hal tersebut dikarenakan terbatasnya sumber daya yang ada di Dinas Sosial Kota Sukabumi seperti staf, informasi, wewenang dan fasilitas. Sehingga menimbulkan tidak efektifnya dalam penanganan permasalahan PMKS di Kota Sukabumi.

Berdasarkan teori Edward III, bahwa ada hal-hal penting yang perlu dicermati, yaitu: efek disposisi, melakukan pengaturan birokrasi (staffing the bureaucratcy) dan insentif.

\section{a. Efek Disposisi}

Pemilihan personil pelaksana atau staf belum melaksanakan kebijakan-kebijakan yang diinginkan. Hal tersebut bisa dilihat dalam menangani permasalahan PMKS dengan bentuk penjangkauan dan pelatihan belum terasakan oleh sasaran kebijakan yaitu informan 3 , hal tersebut disebabkan oleh terbatasnya sumber daya yang ada di Dinas Sosial Kota Sukabumi seperti staf, informasi, wewenang dan fasilitas. Sehingga menimbulkan tidak efektifnya dalam penanganan permasalahan PMKS di Kota Sukabumi.

b. Melakukan Pengaturan Birokrasi (staffing the bureaucracy)

Keterbatasan sumber daya yang ada di Dinas Sosial Kota Sukabumi seperti staf, informasi, wewenang dan fasilitas menyebabkan kurangnya kemampuan, kapabilitas, dan kompetensinya dalam menangani permasalahan PMKS. 


\section{ARTIKEL}

\section{c. Insentif}

Meskipun peningkatan insentif dilakukan, hal tersebut akan sia-sia saja apabila

Dinas Sosial Kota Sukabumi masih kurang dalam hal sumber daya seperti staf, informasi, wewenang dan fasilitas.

Rumah singgah dapat berpengaruh baik terhadap PMKS yang nantinya mengalami banyak perubahan baik yang didukung dengan para pelaksana kebijakan yang menjalankan tugasnya secara maksimal. Maka dari itu peran penting dari rumah singgah sangatlah dibutuhkan untuk PMKS agar dapat mengembalikan fungsi sosial PMKS dan peran dari pelaksana kebijakan atau staf yang mumpuni menjadi sangat penting dalam rumah singgah agar efektif dalam mengurangi permasalahan PMKS di Kota Sukabumi. Dengan adanya rumah singgah, hal tersebut harus di imbangi dengan kualitas para pelaksana kebijakan yang mumpuni yang di dukung dengan pemanfaatan sumber daya yang sesuai dan perlu ada nya program-program yang efektif dalam mengurangi permasalahan PMKS di Kota Sukabumi.

Pembinaan harus diimbangi dengan kualitas dari para pelaksana kebijakan yang mengetahui tentang tugas dan melaksanakan tugasnya sesuai dengan apa yang diharapkan, sumber daya yang mencukupi juga menjadi faktor pendukung agar dalam pelaksanaan pembinaan dapat terlaksana secara efektif. Terbatasnya SDM, dana, sarana dan prasarana dapat menunjukan bahwa sumber daya masih belum mencukupi dan dapat menimbulkan permasalahan, seperti kurang teratasinya penanganan permasalahan PMKS di Kota Sukabumi. Peran penting Dinas Sosial dalam pengoptimalan kualitas sikap para pelaksana kebijakan atau disposisi agar informan 3 dapat menerima dengan baik bentuk pembinaan yang diberikan oleh Dinas Sosial Kota Sukabumi meskipun belum ada rumah singgah.

4. Struktur Birokrasi

Berdasarkan hasil observasi dan wawancara tersebut dapat diinterpretasikan bahwa penjangkauan dilakukan sebanyak 3 kali dalam satu tahun dan pelatihan dilakukan 1 kali dalam satu tahun. Prosedurnyapun sesuai dengan SOPs yang ada, serta PMKS itu harus ditangani secara profesional dengan sumber daya yang mencukupi. Namun pada kenyataan nya permasalahan PMKS meskipun sudah sesuai SOPs masih saja tetap ada dan bertambah, hal tersebut dikarenakan kurang nya sumber daya yang ada di Dinas Sosial Kota Sukabumi.

Apabila dilihat dari teori Edward III, ada dua karakteristik yang dapat mendongkrak kinerja struktur birokrasi atau organisasi ke arah yang lebih baik, yaitu: membuat standard operating procedures (SOPs) yang lebih fleksibel dan melaksanakan fragmentasi. 
a. Membuat standard operating procedures (SOPs) yang lebih fleksibel

Pada dasarnya Dinas Sosial mengalami hambatan dalam melaksanakan kegiatankegiatannya pada setiap harinya yang sesuai dengan standar yang telah ditetapkan, hal tersebut disebabkan oleh kurang nya sumber daya yang menjadi faktor pendukunga dalam penanganan permasalah PMKS, seperti kurang nya staf dan fasilitas.

b. Melaksanakan fragmentasi

Dalam penelitian ini Dinas Sosial belum dapat menyebar tanggungjawab pada beberapa unit kerja yang sesuai dengan bidangnya masing-masing, dikarenakan dalam setiap bidangnya masing-masing masih kekurang sumber daya manusianya yang menyebabkan kurang optimalnya pelaksanaan penanganan permasalahan PMKS.

Apabila Kota Sukabumi mempunyai rumah singgah tentunya dapat berpengaruh baik terhadap PMKS yang nantinya mengalami banyak perubahan baik yang didukung dengan prosedur atau aktivitas terencana rutin dilaksanakan sesuai dengan standar yang telah di tetapkan. Maka dari itu peran penting dari rumah singgah sangatlah dibutuhkan untuk PMKS agar dapat mengembalikan fungsi sosial PMKS dan peran dari prosedur atau aktivitas terencana rutin dilaksanakan sesuai dengan standar yang telah di tetapkan menjadi sangat penting dalam rumah singgah agar efektif dalam mengurangi permasalahan PMKS di Kota Sukabumi. Hal tersebutpun harus di imbangi dengan prosedur atau aktivitas terencana rutin dilaksanakan sesuai dengan standar yang telah di tetapkan dan di dukung dengan pemanfaatan sumber daya yang sesuai dan perlu ada nya program-program yang efektif dalam mengurangi permasalahan PMKS di Kota Sukabumi.

Dalam pembinaan tentunya harus di imbangi dengan kualitas dari para pelaksana kebijakan yang mengetahui tentang tugas dan melaksanakan tugasnya sesuai dengan apa yang diharapkan dan prosedur atau aktivitas terencana rutin dilaksanakan sesuai dengan standar yang telah di tetapkan. Sumber daya yang mencukupi juga menjadi faktor pendukung agar dalam pelaksanaan pembinaan dapat terlaksana secara efektif. Terbatasnya SDM, dana, sarana dan prasarana dapat menunjukan bahwa sumber daya masih belum mencukupi dan dapat menimbulkan permasalahan, seperti kurang teratasinya penanganan permasalahan PMKS di Kota Sukabumi. Peran penting Dinas Sosial dalam pengoptimalan prosedur atau aktivitas terencana rutin dilaksanakan sesuai dengan standar yang telah di tetapkan agar 
informan 3 dapat menerima dengan baik bentuk pembinaan yang diberikan oleh Dinas Sosial Kota Sukabumi meskipun belum ada rumah singgah.

Dalam pelaksanaan kebijakan penyelenggaraan kesejahteraan sosial oleh Dinas Sosial di Kota Sukabumi di temukan beberapa faktor penghambat berjalannya suatu kebijakan. Faktor penghambat tersebut yaitu sebagai berikut:

1. Masyarakat dan PMKS belum mengetahui tentang Rumah Singgah.

2. Sumber daya yang belum mencukupi baik itu dari staf, informasi, wewenang dan fasilitas.

3. Kualitas dari para pelaksana kebijakan yang mengetahui tentang tugas dan melaksanakan tugasnya belum sesuai dengan apa yang diharapkan.

4. Pengoptimalan prosedur atau aktivitas terencana rutin belum dilaksanakan sesuai dengan standar yang telah di tetapkan.

Berdasarkan ke empat faktor pendukung keberhasilan dalam implementasi kebijakan menurut Edward III, salah satu yang mendukung implementasi kebijakan penyelenggaraan kesejahteraan sosial oleh Dinas Sosial di Kota Sukabumi yaitu di tahun 2020, rumah singgah akan mulai beroperasi, sehingga pelaksanaan penyelenggaraan kesejahteraan bisa terlaksana dengan baik.

\section{E. KESIMPULAN}

Hasil penelitian mengungkapkan bahwa implementasi kebijakan penyelenggaraan kesejahteraan sosial oleh Dinas Sosial di Kota Sukabumi belum terlaksana secara maksimal, dikarenakan kurangnya sumber daya manusia dan tidak adanya fasilitas untuk pembinaan dan pelatihan/rehabilitasi seperti rumah singgah. Pemerintah Kota Sukabumi seharusnya memiliki rumah singgah untuk penanganan penyandang masalah kesejahteraan sosial agar dinas sosial dapat turut serta dalam pelaksanaan pembinaan dan pelatihan/rehabilitasi. Pemerintah Kota Sukabumi juga hendaknya membuat program pembinaan lanjutan, pembinaan lanjutan ini bertujuan untuk memelihara dan meningkatkan kemampuan sosial ekonomi dan mengembangkan rasa tanggung jawab serta kesadaran hidup bermasyarakat.

Faktor penghambat dalam implementasi kebijakan penyelenggaraan kesejahteraan sosial (upaya pengadaan rumah singgah) adalah ketidaktahuan masyarakan maupun PMKS tentang tentang rumah singgah, sumber daya yang belum mencukupi, kualitas dari para pelaksana kebijakan, pengoptimalan prosedur atau aktivitas terencana rutin belum dilaksanakan sesuai dengan standar yang telah di tetapkan. Sementara faktor pendukung 
dalam implementasi kebijakan penyelenggaraan kesejahteraan sosial (upaya pengadaan rumah singgah) adalah fasilitas rumah singgah yang akan segera ada pada tahun 2020 .

\section{DAFTAR PUSTAKA}

Afrizal. (2014). Metode Penelitian Kualitatif: Sebuah Upaya Mendukung Penggunaan Penelitian Kualitatif dalam Berbagai Disiplin Ilmu. Jakarta: PT Raja Grafindo.

Agustino, L. (2016). Dasar-Dasar Kebijakan Publik. Bandung: CV Alfabeta.

Anandar, R., Wibhawa, B., \& Wibowo, H. (2015). Dukungan Sosial Terhadap Anak Jalanan di Rumah Singgah, 8.

Arifin, S. (2017). Pembinaan Anak Jalanan Oleh Dinas Sosial. Lampung: Skripsi Program Pemikiran Politik Islam. Fakultas Ushuluddin dan Studi Agama.

Moleong, L. J. (1999). Metodologi Penelitian Kualitatif. Bandung: PT Remaja Rosdakarya.

Peraturan Pemerintahan Republik Indonesia Nomor 39 Tahun 2012, tentang Penyelenggaraan Kesejahteraan Sosial.

Peraturan Daerah Kota Sukabumi No. 6 Tahun 2016, tentang Penyelenggaraan Kesejahteraan Sosial.

Purwanto, E. A., \& Sulistyastuti, D. R. (2015). Implementasi Kebijakan Publik: Konsep dan Aplikasinya di Indonesia. Yogyakarta: Gava Media.

Sirojudin, M. (2015). Peran Rumah Singgah Cahaya Anak Negeri Dalam Meningkatkan Akhlak Anak Jalanan. Jakarta: Skripsi Manajemen Dakwah. Fakultas Dakwah dan Ilmu Komunikasi.

Sugiyono. (2016). Metode Penelitian Kuantitatif, Kualitatif, dan R\&D. Bandung: CV Alfabeta. 